\title{
Reflective practice in English language teacher training: From theory to practice
}

\author{
Phan Thi Thu Nga ${ }^{1 *}$ \\ ${ }^{1}$ Ho Chi Minh City Open University, Vietnam \\ *Corresponding author: nga.ptt@ou.edu.vn
}

\begin{abstract}
ARTICLE INFO
DOI: $10.46223 / \mathrm{HCMCOUJS.}$ soci.en.9.2.259.2019

Received: November $11^{\text {th }}, 2019$

Revised: December 10 ${ }^{\text {th }}, 2019$

Accepted: December 13 ${ }^{\text {th }}, 2019$

Keywords:

classroom English, reflection, reflective practice, teacher-trainees

ABSTRACT

The main aim of the study presented in this article is to examine what teacher-trainees could learn from the reflective practice task after their teaching performance in the English Teaching Practice Course. Participants of this study were teacher-trainees (or senior students majoring in English language teaching) in the first semester of the academic year 2018-2019. Each trainee had his/her lesson recorded when s/he was conducting an English lesson in front of his/her peers. Then each watched the lesson and found some strengths and weaknesses in this lesson and submitted this task to the trainer. The findings from this reflective task indicated that trainees could recognize not only their errors in using classroom English but also four main weaknesses in their teaching skills. Moreover, the findings from the questionnaire after the course ended reveal that these trainees classified their errors into seven groups and suggested solutions to overcome such problems. Some limitations and recommendations for further study on reflection can be seen at the end of this article.
\end{abstract}

\section{Introduction}

Quality assurance has been one of the major objectives of many universities all over the world in general and in Ho Chi Minh City Open University (HCMCOU) in particular. In order to assure the quality of teaching and learning, many changes in the curriculum, syllabus, materials, teaching and learning methods and especially assessment methods have recently been made.

Traditionally, students' learning outcome of a subject in the curriculum was assessed once at the end of the course. In other words, a summative assessment was adopted for many years. Later both formative and summative assessment methods have been implicated in many courses at HCMCOU, and students' learning outcomes have continuously been assessed in various ways such as mid-term tests, group assignments, oral presentation, project-based tasks, portfolios and final term tests. Most of these assessment tasks have been done by the instructors. Similarly, these assessment methods can be recognized in English teacher training courses at HCMCOU. In recent years, the teacher trainer as well as the author of this article has 
encouraged teacher-trainees to use provided guidelines on self-assessment of their learning outcomes after they completed group assignments. Especially, in the English Teaching Practice course teacher- trainees have been encouraged to reflect on their lessons after they fulfilled their teaching performance. This kind of reflective task helps trainees think carefully and deeply about the strengths and weaknesses in their lessons so that they will find out some solutions to overcome their weaknesses after that. This way of training teachers of English is in line with one of the aspects of what is called "the reflective approach" in the pre-service teacher education, and the concept of reflection as a way of linking theory and practice and developing a professional competence (Mardešić, 2018, p. 3).

Although the reflective practice has been adopted in English teacher training courses in HCMCOU for a few years, there has not been an empirical study on the effectiveness of this approach. Some questions such as what can teacher-trainees learn after such a reflective task? Can they search for ways to improve their lessons later? This has arisen in the author's mind; therefore, an investigation on reflective practice in one of the English teacher training courses at HCMCOU was conducted in order to answer such questions. In the following part of this article, some relevant literature on reflective practice will be presented, and it will be the theoretical background for this study.

\section{Review of relevant literature}

\subsection{Definitions of reflection}

In literature, there are several different definitions of reflection. Historically, as cited by Stanley (2012), John Dewey defined reflection as an activity based on active, persistent and careful consideration of any belief or practice in light of reasons that support it and further consequence to which it leads. Attitudes of open-mindedness, responsibility, and wholeheartedness that require teachers to examine multiple perspectives of their own and other's beliefs and practices are essentials to reflective action (Dewey, 1910). Reflection in education demands teachers' systematic thinking and logical, rational, and gradual analyzing of the teaching environment (Korthagen, 1993). Williams and Burden (1997) consider reflection a process of bringing out one's own implicit knowledge and personal theories. They argue that the task of the reflective practitioner is to make this implicit knowledge explicit by reflection on action, by constantly generating questions and checking our emerging theories with both personal past experiences and with the reflection of others (Williams \& Burden, 1997, p. 54). Moreover, reflective teaching, as stated by Wallace (1998), is the critical exploration of one's own teaching practice and essential to long-life professional development.

Thornbury (2006, p. 194) defines reflection as a key stage in an experiential learning cycle that also includes planning, action and learning. Reflection involves more than simply remembering. It means being able to think critically about the experience, to identify problems, and 're-frame' these problems, i.e., to consider them in a new light, in order to identify possible solutions, and to formulate these as a plan of action. It is claimed that self-directed reflection of this type is a characteristic of professional expertise. In other words, Harmer (2007, pp. 410413) believes that reflection is simply a matter of teachers' thinking about what is happening in their lessons. 


\subsection{Reasons for reflective practice in teacher training}

Reflective practice is supported by many experts in English teacher education. In the first regard, J. C. Richards and Nunan (1990, p. 4) and Wajnryb (1992, p. 10) claim that teachertrainers need to understand that teacher preparation means developing in teacher trainees lowinference skills such as giving instructions or asking questions as well as high inference skills such as planning and decision making. In addition, Prabhu (1987 as quoted in Wajnryb, 1992, p. 11) conceptualizes this view as 'equipping' or providing teacher-trainees with pedagogical knowledge and skills for immediate use, and 'enabling' or helping them develop the ability to independently handle professional affairs. Therefore, teacher-trainers can 'equip' teacher trainees with low inference skills but to 'enable' them with high inference skills which must be involved in reflective practice. Similarly, Wallace (1991) believes that reflective practice is essential to teacher development because it is through reflection on professional action that professional expertise is developed (Wallace, 1991, p. 82). In addition, Wallace (1991) suggests a reflective practice model for professional development in teacher training.

As cited by Bailey (2006), the first (among four) principle of language teacher evaluation is encouraging reflective practice, which is directly related to reflective teaching. This model of teacher development emphasizes reflecting on one's own practice as a means of improving that practice (Bailey, 1997; Richards \& Lockhart, 1994). From the figure 1., it can be understood that Wallace (1991) believes "ways should be found making the relationship between received knowledge and experiential learning reciprocal, not one-way, so that the trainee can reflect on the received knowledge in the light of classroom experience, and so that classroom experience can feedback into the received knowledge sessions" (1991, p. 55). Wallace proposes a reflective model of teacher preparation, which emphasizes the link between theory and practice. Therefore, it can be seen that reflection plays a vital role in developing teacher-trainees' professional competence according to the reflective model suggested by Wallace (1991). This teacher training model is also preferred by Wallace and Woolger (as cited by Bailey, 2006, p. 153) because the responsibility for the development of professional expertise is seen as essentially residing with the trainee by a process of reflecting on his/her own practice.

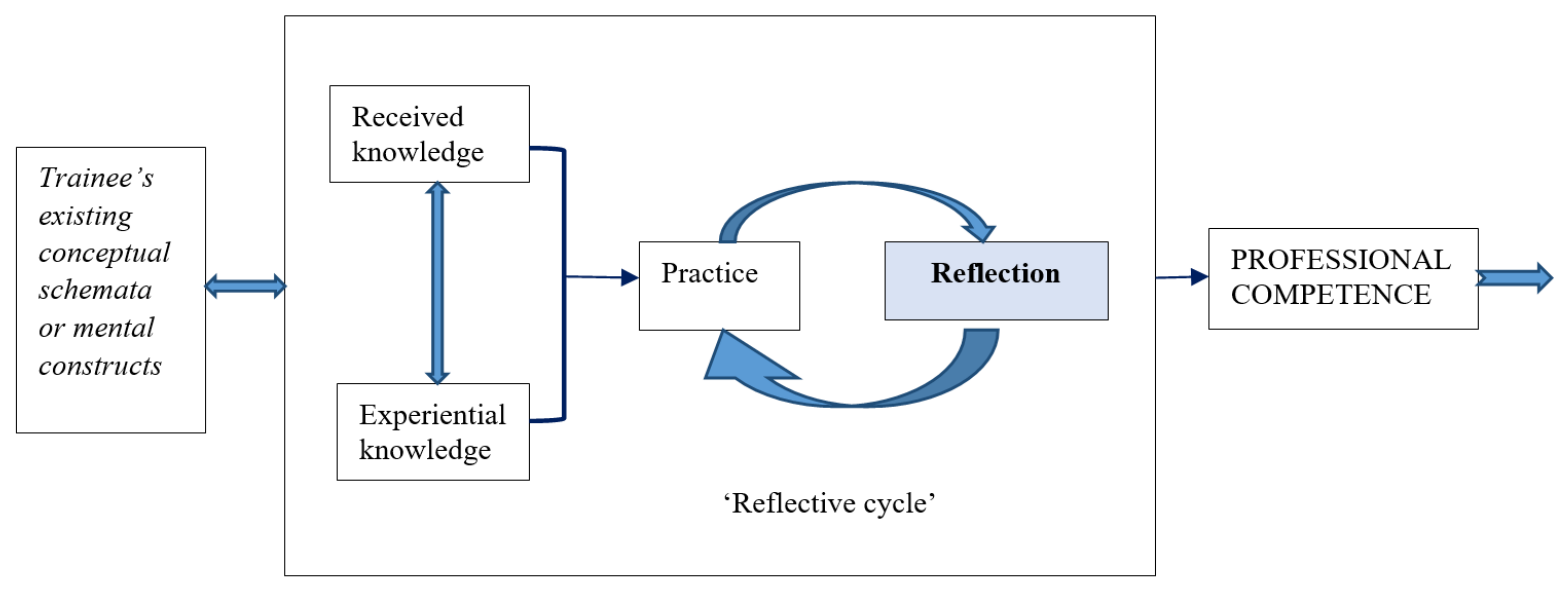

Stage 1

(Pre-training)
Stage 2

(Professional education/development)
GOAL

Figure 1. In Wallace (1991, p. 49) 
In the second regard, reflective practice encourages teachers to develop the skills of considering the teaching process thoughtfully, analytically, and objectively as a way of improving classroom practices, (J. C. Richards, 2002, p. 23). Among authors, it can be recognized that Farrell has many articles and books about reflective practice in teachers' professional development. In Farrell's conclusion (2003), reflective teaching can benefit ESL/EFL teachers in four main ways: (1) reflective teaching helps free the teachers from impulse and routine behavior; (2) reflective teaching allows teachers to act in a deliberate, intentional manner and avoid the "I don't know what I will do today" syndrome; (3) reflective teaching distinguishes teachers as educated human beings since it is one of the signs of intelligent action; and (4) as teachers gain experience in a community of professional educators, they feel the need to grow beyond the initial stages of survival in the classroom to reconstructing their own particular theory from practice. Moreover, Farrell (2016) argues that teachers must continually reshape their knowledge of teaching, and this knowledge is initially developed in teacher training programs, and then it becomes a part of teachers' education throughout their careers if they are engaged in reflective practice. As Farrell (2016) cited, Dewey (1933) warns that teachers who do not want to reflect on their teaching become slaves to routines because their actions are guided mostly by impulse, tradition, and/or authority rather than by informed decision making, and this reliance on routine and daily repetitive actions gradually leads to burnout. In order to avoid such burnout, Farrell (2016) thinks that teachers should engage in reflective practice. That means they can take time to stop and think about what is happening in their teaching to make sense of it so that they can learn from their experiences rather than mindlessly repeat them year after year.

\subsection{When and how to practice reflection}

Many researchers in teacher education suggest that reflective practice should be done at an early stage of teacher training. When teacher-trainees are first introduced to various approaches and methods, they need opportunities for their experimental lessons in a safe classroom. Therefore, micro-teaching in the classroom where teacher-trainees take a turn to conduct their lessons in front of their peers is an ideal way for reflection practice. As Wallace (1991) suggested, four main steps of microteaching traditionally include (1) the briefing or orientation, (2) teaching the lesson, (3) the critique or discussion, and (4) re-teaching the lesson. When teacher-trainees reflect on microteaching, they can apply and assess concepts they are learning, and they can learn how to give and receive constructive feedback. This early experience increases their confidence and establishes observation and self-reflection as a standard practice that will continually develop their teaching skills.

According to Harmer (2007), there are four main ways of practicing reflection. First of all, keeping journals is a very powerful reflective device allowing teachers to use their introspection to make sense of what is going on around them. Second, teacher-trainees should look inside themselves and seek to understand both positive and negative things in their lessons in order to overcome negative ones. Third, recording their lessons and listening or/and watching them leads teacher-trainees to reflect on what happened and think of how they might do things differently in the future. Finally, learning from various methodology books, journals and magazines produced for teachers of English is also an effective way for reflective practice. Besides Harmer (2007), Farrell (2016) suggests that language teachers can choose a number of activities that facilitate reflective practice over the course of their professional careers. For instance, teacher-trainees can choose to reflect with and through teaching journals, critical friends, teacher development groups, classroom observations, and/or action research. Some of 
these can be used alone or in combination with peers, depending on each teacher's level of comfort sharing their ideas, issues, and concerns.

\subsection{Video for reflective practice in teacher training}

Orlova (2009) suggests the teacher-trainer should encourage teacher-trainees to use videotaping lessons to observe, analyze, and discuss classroom performance after their microteaching. It is true that the use of recording lessons for self-observation offers teacher-trainees many benefits such as (1) allowing them to distance themselves and be dispassionate about their teaching; (2) helping them to notice and respond to both strong and weak aspects of their teaching, (3) allowing them to review and re-examine their lessons many times; and (4) enabling them to reflect on not only their non-verbal aspects of their teaching but also on their communicative competence and their style of teacher-student interaction.

As Ostrosky, Mouzourou, Danner, and Zaghlawan (2012) cited from different researchers, video can be a powerful tool to support teacher-trainees learning thanks to a lot of advantages. In fact, viewing a video of their own teaching helps teacher-trainees or pre-service teachers pay attention to details of interactions with learners that may be hard to notice while teaching. Video also allows teacher-trainees to engage in conversation and draw on collective experiences to gain a better understanding of how particular strategies and lessons can be adapted to meet the needs of their learners.

In Payant's (2014) review of relevant literature, using video recording lessons for reflective practice offers teacher-trainees a lot of advantages. First, given the elusive nature of classroom teaching, videos provide valuable input for teachers by capturing what unfolded in real-time and making some of the captured dimensions of the teaching events more permanent. Second, videos can be viewed on repeated occasions, and this may help teacher-trainees gain in-depth insights about their teaching, and is useful for further, more focused reflections on what actually transpired during their microteaching. Also, videos help teacher-trainees concentrate on the quantity of teacher talk, the clarity of the instructions, and the provision of feedback/praise. Finally, videos enable teacher-trainees to focus on their own teaching practices but also redirect their attention to their learners' needs and interaction patterns.

\subsection{Findings from previous studies}

Reflective practice has easily been found in various studies conducted by many researchers and experts in English education and in English teacher education in different countries all over the world for several years.

Ene and Riddlebarger (2005) concluded the questionnaire was useful in eliciting a fair amount of critical thinking and integration of prior knowledge, new content, and personal experience; for the teacher trainer, it worked as a tool for assessing student learning and planning lessons. In his study of two Hong Kong Universities, Lee (2007) found that dialogue and response journals provided opportunities for pre-service teachers to engage in reflective thinking, so he recommended teacher educators should use journals as a tool for promoting reflection in pre-service teacher preparation. According to Orlova's findings (2009), during their pre-service, teacher-trainees engaging in recording and reflecting on their micro-teaching typically show an increase in self-awareness; they realize that teaching is a complicated process and that there are many aspects they have to learn and improve. They also reveal an improved 
ability to shift roles from actor to director; and they internalize the idea that reflection on their classroom behavior is a key factor in their professional development.

In an empirical study conducted by Pellegrino and Gerber (2012), the utility of videorecording self-analysis as an effective means of reflective practice for teachers was examined, and two remarkable findings were identified: (1) engaging in this guided reflective activity brought teachers a heightened awareness of the strengths and weaknesses in their teaching, and (2) employing the observation instrument, coupled with the formalized act of video-recording analysis allowed them to focus on details of teaching often overlooked in less formal reflective practice or formal evaluation. Later, R. D. Richard's findings (2013) from the study of two Thailand universities demonstrate that students liked peer observation, and that they reflected on their teaching which helped them modify their teaching practices and beliefs. From these findings, it can also be realized that the students would engage in reflective teaching in future teaching.

Noormohammadi's results (2014) proved that there was a positive relationship between teacher reflective practice, teacher self-efficacy and autonomy; also reflection elements had positive relations with self-efficacy and autonomy components. Obviously, the reflective practice would help teachers to foster their effectiveness as well as independence.

According to Coffey's conclusion (2014), students indicated that the use of video, in conjunction with written feedback from teachers, had enhanced their capacity to reflect on their teaching skills. As Payant (2014) concluded the results from the qualitative analysis of the participants' post-microteaching reflective reports showed that they used videos to explore their professional and non-native identities, practical and pedagogical knowledge base. The results are discussed with respect to their implications for educational practice with pre-service teachers of English. According to Karalik's (2015) conclusion, from student teachers' views, writing observation and reflection reports were among the least effective assessment methods of their performance in English teaching practicum. Azizah, Nurkamto, and Drajati (2018) found that pre-service teachers of English need to be more experienced in order to be able to utilize reflective practice properly and professionally.

In brief, it can be seen that reflection as well as the reflective practice has been one of the popular issues that attract many researchers and experts in teacher education in general and training programs for teachers of English as a foreign and second language in many countries all over the world. In the next part of this article, an examination of the reflective practice of teacher-trainees in the English teaching practice course at HCMCOU will be described.

\section{Research methods}

The analysis of relevant literature above and previous findings of many different authors have proved the vital role of reflection in English teacher training. Therefore, the teacher-trainer (also the author of this article) expects teacher-trainees to practice reflection from the early stage of their professional experiences. The main aim of this investigation is to find what teachertrainees could learn from reflective practice. The presented findings were collected from the reflection task that teacher-trainees submitted after they fulfilled their teaching presentation and their responses in the questionnaire at the end of the English Teaching Practice course.

The participants of this study were 68 teacher-trainees (in two classes) who attended the English Teaching Practice course in the first semester of the academic year 2018-2019. These 
classes started in September, 2018 and ended in November, 2018. In this course, each teachertrainee presented two English lessons for high school learners in Vietnam (grades 10 and 11) twice. The first lesson was conducted in groups of three or four in front of their peers (classmates) who were supposed to be high school learners. The second one was performed by one teachertrainee in front of his/her peers after s/he received feedback on his/her co-teaching lesson from the teacher-trainer and their peers. While performing an English lesson in the classroom, each individual trainee had a classmate record his/her lesson by using a smartphone. After each class meeting, teacher-trainees were requested to watch their lessons and think of what had been done well in the lesson and what needed improving. Especially, teacher-trainees were encouraged to focus on their use of classroom English in order to figure out their errors and suggest ways to overcome them, and they had to submit their reflective task at the end of the course. Besides the data from the reflective practice task, the questionnaire was used to collect some data about trainees' responses (about their problems and solutions) after they watched their recorded lessons at home. The findings from the collected data will be interpreted below.

\section{Data analysis}

The teacher-trainers major purpose when asking teacher-trainees to carry out a reflective practice task after their teaching presentation was helping them identify their problems in using classroom English when giving instructions and making questions for setting contexts, building up information, assessing learners' prior knowledge, checking the meaning of language items (words/structures) and checking learners' understanding of instructions so that they could find ways to improve their ability to use English in their teaching. However, the findings from the collected data exceeded the trainer's expectations. The presented findings are divided into two main parts: (1) findings from the reflective practice task collected from 68 teacher-trainees from week 4 to week 10; (2) findings from the questionnaire collected from 50 trainees three weeks after the course ended.

\subsection{Findings from the reflective practice task}

\section{Classroom English problems}

The information in Table 1 indicates the errors that teacher-trainees made when they were conducting their lessons, and they also suggested ways to overcome their problems after they identified them when watching their recorded lessons after class. 30 kinds of problems listed below were randomly selected from what trainees figured out when they watched their recorded lessons after class.

\section{Table 1}

Teacher-trainees' language problems and how to overcome them

\begin{tabular}{|l|l|}
\hline What teacher-trainees said/did in class & \multicolumn{1}{|c|}{$\begin{array}{c}\text { What they should say/do } \\
\text { (Self-correction) }\end{array}$} \\
\hline $\begin{array}{l}\text { 1. Any other? (when one of the students } \\
\text { gave a wrong answer in the while reading } \\
\text { stage) }\end{array}$ & $\begin{array}{l}\text { I'm sorry. That's not the answer that I'm } \\
\text { looking for. Who can help her? Has anyone } \\
\text { got a different answer? }\end{array}$ \\
\hline $\begin{array}{l}\text { 2. I would like you to work in pairs to share } \\
\text { your collections, you have } 2 \text { minutes. }\end{array}$ & $\begin{array}{l}\text { I would like you to work in pairs to share your } \\
\text { collections. Then I call some pairs to show up }\end{array}$ \\
\hline
\end{tabular}




\begin{tabular}{|c|c|}
\hline What teacher-trainees said/did in class & $\begin{array}{l}\text { What they should say/do } \\
\text { (Self-correction) }\end{array}$ \\
\hline $\begin{array}{l}\text { Then I call some pairs to show up. You } \\
\text { can start now. (in the pre-stage of the } \\
\text { writing lesson) }\end{array}$ & $\begin{array}{l}\text { your ideas. You can spend } 2 \text { minutes on this } \\
\text { task. }\end{array}$ \\
\hline $\begin{array}{l}\text { 3. "so" and "very good" many times (in a } \\
\text { grammar lesson) }\end{array}$ & $\begin{array}{l}\text { Use first, next, after that when instructing } \\
\text { learners how to do a grammar exercise; use so, } \\
\text { therefore, as a result when expressing results } \\
\text { and use different words/phrases such as a } \\
\text { good/great answer, a brilliant idea when } \\
\text { praising learners. }\end{array}$ \\
\hline $\begin{array}{l}\text { 4. When giving instructions, I always use } \\
\text { "you, guys". }\end{array}$ & $\begin{array}{l}\text { I will avoid using "you, guys" if my learners } \\
\text { are adults. }\end{array}$ \\
\hline $\begin{array}{l}\text { 5. I always pronounce "the" incorrectly } \\
\text { when it is used before a vowel sound. }\end{array}$ & $\begin{array}{l}\text { I will try to overcome this kind of mistake in } \\
\text { my future lessons. }\end{array}$ \\
\hline $\begin{array}{l}\text { 6. I didn't make various questions when } \\
\text { checking learners' answers. }\end{array}$ & $\begin{array}{l}\text { I should vary my questions, for example: } \\
\text { What's the answer to number } 1 \text { ? } \\
\text { What have you answered for question 2? } \\
\text { Did anybody have a different answer? } \\
\text { Let's go on to number } 3 \text {. }\end{array}$ \\
\hline $\begin{array}{l}\text { 7. I always used "OK" when checking } \\
\text { learners' answers. }\end{array}$ & $\begin{array}{l}\text { I should use different words/phrases such as } \\
\text { "good, right, nice, well-done" to respond to } \\
\text { learners' correct answers. }\end{array}$ \\
\hline $\begin{array}{l}\text { 8. Class was quite noisy. I have asked } \\
\text { learners to keep quiet by saying: "Class, } \\
\text { I afraid it's too noisy now. Keep quiet, } \\
\text { please." }\end{array}$ & $\begin{array}{l}\text { I should say: "It's too noisy now. Please keep } \\
\text { quiet!" }\end{array}$ \\
\hline $\begin{array}{l}\text { 9. I made a lot mistakes in the final sound } \\
\text { ' } s \text { ' during my lesson. }\end{array}$ & $\begin{array}{l}\text { I hope I could overcome this problem in my } \\
\text { next lesson. }\end{array}$ \\
\hline 10.A louder please! & Would you mind speaking louder please? \\
\hline
\end{tabular}

Source: The researcher's data analysis

\section{Other problems}

In addition to errors in using classroom English, teacher-trainees could recognize their weaknesses when they watched their recorded lessons. Their problems can be classified into four categories: (1) ability to follow procedures and use activities to help learners develop/improve their language skills; (2) ability to set up and manage pair/group activities, 
prepare and use resources as well as teaching aids; (3) ability to monitor learners, provide feedback and correct learners' mistakes; and (4) ability to create a positive learning atmosphere to ensure learners' involvement.

(1) Following procedures and using activities/tasks

(T1): I should use concept questions to check learners' comprehension of the grammar structures before I asked them to do exercises (in a grammar lesson).

(T2): I should have some challenging questions in the post-listening stage to help learners develop critical thinking after listening to comprehension questions.

(T3): I shouldn't use a game at the start of a writing lesson because it is very timeconsuming.

(T4): In a speaking lesson, I should limit the information (language input) as not to overburden learners as well as to control time in speaking activities.

(T5): The vocabulary review section at the start of the lesson was not necessary because it was easy. I should find another way to get learners engaged in the writing lesson. All of the stages in my writing lesson were not logically linked, either.

(2) Setting up and managing activities, preparing and using resources and aids

(T6): I should reduce the light in the classroom during the video clip section so that learners could find it comfortable to view the video clips.

(T7): My instructions for listening tasks should be shorter, and I should combine both verbal and non-verbal instructions.

(T8): I didn't give clear instructions for writing activities, so I realized that learners couldn't know what to do when I watched my recorded lesson.

(T9): When designing slides, I should consider the font, size and color of words on slides. I think learners had difficulty in reading words on my slides.

(T10): There were some grammar mistakes in the examples on my slides. I will check for grammar mistakes carefully when I prepare slides in the future.

(3) Monitoring, giving feedback and correcting learners' mistakes

(T11): I should let learners check their answers with their partners to increase their confidence before I asked some of them to give answers in the feedback section; and this should be done orally instead of asking learners to write their answers on the board.

(T12): I should repeat each learner's answer after giving feedback so that other learners could follow the answers easily.

(T13): I didn't correct learners' mistakes successfully because I couldn't make eliciting questions or couldn't give some prompts to encourage them to self-correct their mistakes.

(T14): I called some learners to go to the board and write the suitable words. Therefore, it was not necessary for me to call each student to stand up again and read his/her words.

(T15): When correcting learners' answers, I always said "yes, correct”. I think I should vary my praise by saying "well done", "you are an excellent student" or "good job" to 
encourage learners.

(4) Creating a positive learning atmosphere to ensure learners' involvement

(T16): I didn't maintain my eye contact with learners during the lesson; and sometimes I ignored them when they didn't concentrate on class activities. These are my weak points.

(T17): I need to pay more attention to the learners by observing them. There were some learners who didn't know what was happening in class, so when I nominated them, they were surprised and didn't know where and what they were in the lesson.

(T18): I lacked self-confidence when I was standing in front of the class. I hesitated a lot when giving instructions because I was afraid of making pronunciation mistakes.

(T19): My voice was not loud and powerful enough, so learners didn't pay attention to my instructions in a speaking lesson. I will try to overcome this weakness of mine.

(T20): I didn't know why many learners laughed while I was teaching. I felt timid and scared of being laughed. After watching my lesson at home, I think learners laughed a lot during my lesson because of my voice and my facial expressions. I will try to be friendly and adjust the volume of my voice.

\subsection{Findings from the questionnaire}

Although there were 68 teacher-trainees who attended the English teaching practice course and submitted their reflective practice tasks after they finished teaching in class, only 50 $(73.5 \%)$ answered the questionnaire three weeks later.

The analysis of 50 trainees' responses to the questionnaire indicated that the time they watched their recording lessons ranged from 6 to 1 . Only a few (3 out of 50) of trainees watched their lessons once; and a few ( 2 out of 50 watched) five and six times; and most of them watched from 2 to 4 times in order to identify good things and things that needed improving. More than half of trainees ( 27 out of 50) watched their recording lessons and discuss them with their peers (classmates); and the rest did by themselves.

Figure 2. Classification of errors in using classroom English

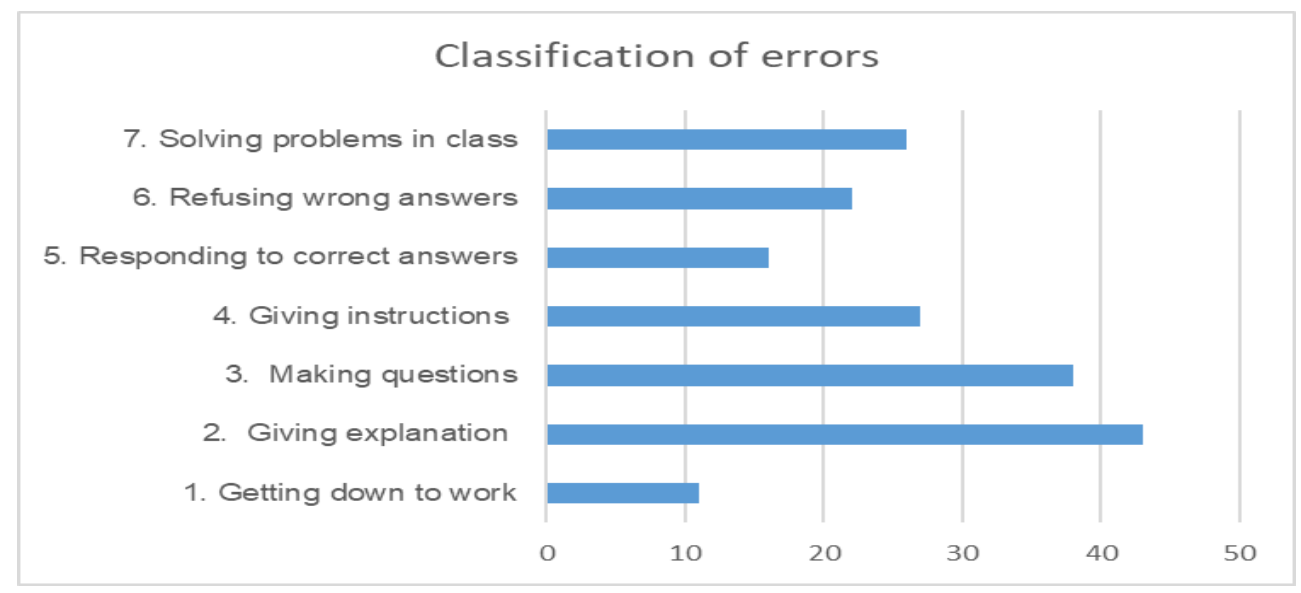

The information in Figure 2 reveals the kinds of errors that teacher-trainees made in 
their teaching were classified into seven groups. The errors with the highest number of trainees (43 out of 50, occupying 86\%) made when they gave an explanation and highlighted the target language. In addition, trainees identified their errors when they made questions for setting up contexts, building up information, assessing learners' prior knowledge, checking the meaning of language items (words/structures) and checking learners' understanding of instructions. These errors are in the second range (38 out of 50, occupying $76 \%$ ). From the figure above, it can easily be recognized that trainees made errors when giving instructions and this kind of error is in the third range ( 27 out of 50, occupying 54\%). The fourth range on the figure is about errors made when (26 out of 50, occupying 52\%) trainees instructed learners on how to do tasks/exercises. Trainees' difficulties in responding to learners' correct answers can be found on the fifth range (22 out of 50, occupying 44\%), in refusing learners' wrong answers on the sixth range (16 out of 50, occupying $32 \%$ ), and in getting learners down to work when starting the lesson on the lowest range (11 out of 50, occupying 20\%).

The numbers on Figure 3 illustrates the solutions that trainees believe could help them overcome their problems in using classroom English. The first solution that many trainees $(92 \%)$ suggested was that they should read the textbook "Practical Classroom English" in order to find out the correct words/sentences they use when explaining and highlighting the target structures in their lessons. The second solution (74\%) was re-examining the instructor's feedback on the observation sheet because after they finished their lesson in class and submitted the reflective practice task, the instructor gave them the observation sheet in which the good points as well as things need improving were indicated. The third solution (68\%) was reexamining peers' feedback on the observation sheets which were written by other teachertrainees who had dual roles: (1) learners and (2) peers or observers. The other two ways were searching for some professional websites to get useful advice from other teachers or experts (24\%) and reading the textbook "Teaching Knowledge Test" (8\%) because this book includes one unit about teacher's classroom language for their references.

\section{Reading the text book "Practical Classroom English" \\ 2. Re-examining peer feedback on the observation sheets \\ 3. Re-examining the instructor's feedback on the observation sheet \\ 4. Searching for some professional websites \\ 5. Reading the textbook "Teaching Knowledge Test"}

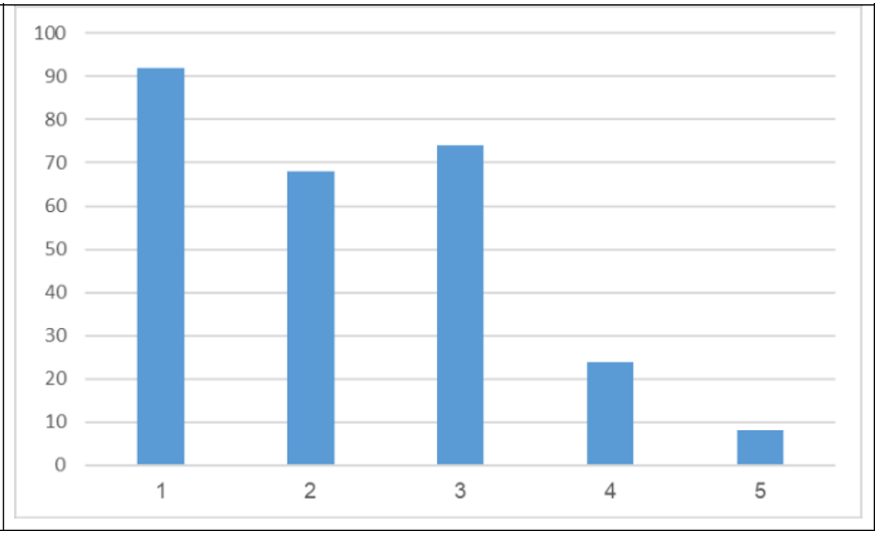

Figure 3. Suggested solutions

\section{Discussion, conclusion and recommendation}

As presented above, teacher-trainees found many remarkable things when they watched their video recording lessons at home. As requested in the reflective practice task, teachertrainees mainly focused on their ability to use classroom English from the beginning to the end of their lessons. Their language errors could be identified into seven categories such as getting 
learners down to work, giving explanations, making questions, giving instructions, responding to learners' answers and solving problems in class, and most of their errors were made when they gave explanations. These findings are in line with Payant (2014)'s conclusions. That means when watching video recording lessons, trainees could pay their attention to the teacher's talk.

In addition to the use of classroom English, teacher-trainees could find out both good things (which are not interpreted in this article) and things that need improving when they watched their recorded lessons. In other words, through this reflective task, they could recognize their strengths and weaknesses in their teaching; and especially they concentrated on details such as following procedures and using activities to help learners develop their skills; setting up and managing pair/group work activities, using resources and teaching aids effectively; monitoring learners, giving feedback and correcting learners' mistakes; and creating a positive learning atmosphere to ensure learners' involvement. These findings are similar to the results of Pellegrino and Gerber (2012), and Payant's (2014).

Besides the data from the reflective task, the information collected from the questionnaire indicated that trainees could not only figure out their problems in using classroom English but also think of possible solutions to overcome their problems, and one of the suggested solutions is re-examining the trainer's written feedback. This conclusion is similar to Coffey's (2014) results. That is, the combination of using video recording lessons and the trainer's written feedback could help trainees reflect on their teaching skills.

In conclusion, the implication of the reflective practice task in the English teaching practice course results in a lot of advantages for teacher-trainees. In fact, this practice task offered them opportunities to reflect on what they did in their lessons, to identify problems in using classroom English and some weaknesses in their teaching skills. They could also find out solutions to overcome such problems in their future lessons. In spite of such positive indicators, some limitations are inevitable. First, the teacher-trainer did not compare and/or contrast the results in each trainee's reflective task with those of the trainer's written feedback as well as his/her peers' written feedback in order to know if their strengths and weaknesses are similar or different from those in their peers' and in the trainer's feedback. Second, the author (also the teacher-trainer) did not investigate these trainees' teaching performance in their teaching practicum in high schools after this course so that it is impossible for the trainer to know whether or not they could overcome weaknesses in their teaching. Therefore, it is recommended that the trainer should conduct two longitudinally empirical studies: one in English teaching practice course and another in English teaching practicum in high schools. Moreover, during their teaching practicum, trainees must carry out at least four lessons, so this offers them many chances to reflect after each lesson. By practicing reflection several times, teacher-trainees will improve not only their classroom English but also teaching skills, which will help them to gain confidence in their teaching jobs after graduation.

\section{References}

Azizah, U. A., Nurkamto, J., \& Drajati, N. A. (2018). Reflective practice: The experiences of pre-service EFL teachers in teaching English. Journal of Language and Linguistic Studies, 14(3), 133-144. 
Bailey, K. M. (1997). Reflective teaching: Situating our stories. Asian Journal of English Language Teaching, 7, 1-19.

Bailey, K. M. (2006). Language teacher supervision: A case-based approach.Cambridge, UK: Cambridge University Press.

Coffey, A. M. (2014). Using video to develop skills in reflection in teacher education students. Australian Journal of Teacher Education, 39(9), 86-97.

Dewey, J. (1910). How we think. London, UK: D. C. Heath.

Ene, E., \& Riddlebarger, C. (2005). Intensive reflection in teacher training: What is it good for? Journal of Academic Writing, 5(1), 158-167.

Farrell, T. S. (2003). Reflective teaching: The principles and practices. English Teaching Forum, 14-21.

Farrell, T. S. (2016). Reflective practice for language teachers. In J. I. Liontas (Ed.), The TESOL Encyclopedia of English language teaching (1st ed.). Hoboken, NJ: John Wiley \& Sons.

Harmer, J. (2007). The practice of English language teaching (4th ed.). London, UK: Pearson Longman.

Karalik, T. (2015). Assessing the performance in EFL teaching practicum: Student teachers' views. International Journal of Higher Education, 4(2), 44-56.

Korthagen, F. A. (1993). Two modes of reflection. Teaching and Teacher Education, 9(3), 317-326.

Lee, I. (2007). Preparing pre-service English teachers for reflective practice. ELT Journal, 61(4), 321-329.

Mardešić, S. (2018). Reflective approach in pre-service foreign language teaching education. In L. António, R. Ruiz \& Cecilia (Eds.), New trends in foreign language teaching. Newcastle upon Tyne, UK: Cambridge Scholars Publishing.

Noormohammadi, S. (2014). Teacher reflection in its relations to teacher efficacy and autonomy. Procedia - Social and Behavioral Sciences, 98, 1380-1389.

Orlova, N. (2009). Video recording as a stimulus for reflection in pre-service EFL teacher training. $\quad$ Retrieved October 21, 2019, from https://americanenglish.state.gov/files/ae/resource_files/09-47-2-f.pdf

Ostrosky, M. O., Mouzourou, C., Danner, N., \& Zaghlawan, H. Y. (2012). Improving teacher practices using microteaching: Planful video recording and constructive feedback. SAGE Journals, 16(1), 16-29.

Payant, C. (2014). Incorporating video-mediated reflective tasks in MATESOL programs. TESL Canada Journal, 31(2), 1-21.

Pellegrino, A. M., \& Gerber, B. L. (2012). Teacher reflection through video-recording analysis. Georgia Educational Researcher, 9(1). doi:10.20429/ger.2012.090101

Richard, R. D. (2013). Peer observation and reflection in ELT practicum. Retrieved October 22, 2019, from https://files.eric.ed.gov/fulltext/ED546863.pdf 
Richards, J. C. (2002). Theories of teaching in language teaching. In J. C. Richards \& W. A. Renandya (Eds.), Methodology in language teaching: An anthology of current practice (pp. 19-25). Cambridge, UK: Cambridge University Press.

Richards, J. C., \& Lockhard, C. (1994). Reflective teaching. New York, NY: Cambridge University Press.

Richards, J. C., \& Nunan, D. (1990). Issues and approaches in teacher education. In Second language teacher education. Cambridge, UK: Cambridge University Press.

Stanley, C. (2012). A framework for teacher reflectivity. TESOL Quarterly, 32(3), 584-591.

Thornbury, S. (2006). An A-Z of ELT: A dictionary of terms and concepts used in English language teaching. Bangkok, Thailand: Macmillan.

Wajnryb, R. (1992). Classroom observation tasks. Cambridge, UK: Cambridge University Press.

Wallace, M. J. (1991). Training foreign language teachers: A reflective approach. Cambridge, UK: Cambridge University Press.

Wallace, M. J. (1998). Action research for language teachers. Cambridge, UK: Cambridge University Press.

Williams, M., \& Burden, R. L. (1997). Psychology for language teachers: A social constructive approach. Cambridge, UK: Cambridge University Press. 